\title{
IDENTITAS KEACEHAN DALAM ISU-ISU SYARIATISASI, KRISTENISASI, ALIRAN SESAT, DAN HEGEMONI BARAT
}

\author{
Al Makin \\ Universitas Islam Negeri Sunan Kalijaga Yogyakarta, Indonesia \\ E-mail: almakin3@gmail.com
}

\begin{abstract}
This article presents a study of the Acehnese religious identity in responding to the issues of sharî‘ $a h$ application in the province, Chirstian mission, deviant sects, and Western hegemony. These themes somehowe play a role in defining the Acehnese identity in the way in which the informants use these themes to project themselves; who they are in relating Islam to the Aceh identity. The spirit of conservatism can be seen in their feeling of being threatened by Christian missionary, deviant sects, and Western hegemony. The application of sharî'ah, on the other hand, gives another legitimacy of the Acehnese identity. Although the issue of shari'ah can be found in other provinces in Indonesia, sharî'ah in Aceh is perceived to be different. This article also presents different voices of the Acehnese who are critical to their fellow Acehnese who support sharî‘ah application, and give negative reaction to the Christian mission, deviant sects and Western hegenomy. This article is based on a fieldwork by interviewing some informants in Banda Aceh in July 2013.
\end{abstract}

Keywords: The Acehnese identity; Chirstian mission; sharî‘ah; deviant sects; Western hegemony.

\section{Pendahuluan}

Aceh mempunyai sejarah, budaya, etnisitas, dan tradisi agama Islam yang unik dan berbeda dibandingkan dengan provinsi lain di Nusantara, ${ }^{1}$ sehingga melahirkan identitas etno-religius yang kuat. ${ }^{2}$

1 Tentang keragaman wilayah Indonesia, agama, dan budayanya dapat dilihat dalam Al Makin, Keragaman dan Perbedaan: Budaya dan Agama dalam Lintas Sejarah Manusia (Yogyakarta: Suka Press, 2016).

2 Hasnil Basri Siregar, "Lessons Learned from the Implementation of Islamic Shari'ah Criminal Law in Aceh," Journal of Law and Religion, Vol. 24, No. 1 (2009), 143; Kamaruzzaman Bustamam-Ahmad, "The Application of Islamic Law in 
Secara historis, sejak era kolonial Belanda, perpaduan etnisitas, adat, dan agama membuat daerah ini mempunyai karakter dan ciri khas yang berbeda dan merupakan elemen resistensi yang kuat terhadap kekuasaan asing. ${ }^{3}$ Tak heran, jika sejak masa kolonial Belanda, Aceh adalah daerah yang sulit ditundukkan, sehingga Belanda memerlukan waktu yang lama, setelah wilayah-wilayah lain di Nusantara takluk di bawah administrasinya. Resistensi terhadap pihak luar dan keteguhan identitas sendiri itu tetap bertahan hingga era kemerdekaan Indonesia. Aceh tetap merasa berbeda dengan kekuatannya terutama di bawah pimpinan karismatik Daud Beureueh yang pada era Soekarno menuntut untuk memberikan Aceh suatu status otonomi khusus dengan sentuhan syariah. Tak berhenti di situ, era selanjutnya masih berlanjut benturan antara identitas dan integrasi nasional. Era Soeharto pada masa Orde Baru menyaksikan alotnya kompromi itu, dan bahkan ini mengerucut dan tajam sesuai dengan perkembangan panasnya Gerakan Aceh Merdeka (GAM), yang didirikan oleh Hasan Tiro tahun 1970-an. Gerakan itu pada dasarnya lebih etnis daripada agamis. Gerakan itu bahkan berpandangan bahwa syariah bisa menjadi penghalang kemajuan. ${ }^{4}$ Respons pemerintah pusat dalam memadamkan semangat independensi di era Orde Baru lewat jalur mililter. Gerakan itu ditekan dengan cara represif. Namun peta berubah ketika masa reformasi dan bersamaan dengan berakhirnya bencana Tsunami. Bencana dan pasca-bencana mengubah pola hubungan antara Aceh dan Jakarta. Perjanjian Helsinki tahun 2005 merupakan usaha perdamaian dengan tawaran kompensasi penerapan

Indonesia: The Case Study of Aceh," Journal of Indonesian Islam, Vol. 1, No. 1 (2007), 135-180.

3 Arskal Salim, “'Shari'a from Below' in Aceh (1930s-1960s): Islamic Identity and the Right to Self-Determination with Comparative Reference to the Moro Islamic Liberation Front (MILF)," Indonesia and the Malay World, Vol. 32, No. 92 (2004), 8099; Arskal Salim, "Dynamic Legal Pluralism in Indonesia: Contested Legal Orders in Contemporary Aceh," Journal of Legal Pluralism, Vol. 10, No. 61 (2010), 1-31; Edward Aspinall, "The Construction of Grievance: Natural Resources and Identity in a Separatist Conflict," The Journal of Conflict Resolution, Vol. 51, No. 6 (2007), 950972; Eka Srimulyani, "Islam, Adat and the State: Matrifocality in Aceh Revisited," Al-Jami'ab: Journal of Islamic Studies, Vol. 48, No. 2 (2010), 321-342.

4 Salim, "Shari'a from Below' in Aceh (1930s-1960s)", 92; Moch. Nur Ichwan, "Official Ulema and the Politics of Re-Islamization: The Majelis Permusyawaratan Ulama, Shariatization and Contested Authority in Post-New Order Aceh," Journal of Islamic Studies, Vol. 22, No. 2 (2011), 204. 
syariah ditawarkan dari Jakarta. ${ }^{5}$ Ini terbukti efektif dalam usaha mengakhiri konflik berkepanjangan, dengan mengangkat identitas Aceh yang tetap berbeda dengan ciri khas kuatnya tradisi agama. ${ }^{6}$ Syariah sebagai daya tawar bagi perdamaian antara pemerintah pusat dan Aceh juga melahirkan fenomena tersendiri, di mana menurut Feener syariah merupakan rekayasa atas ke bawah, namun masyarakat dan pemain lokal juga memanfaatkan momentum. ${ }^{7}$ Unsur politis pusta dan lokal tak lekang dari syariah. Sebagaimana juga di masa reformasi di seluruh Indonesia, ${ }^{8}$ masa itu juga mempengaruhi keterbukaan Aceh; tidak hanya internal Aceh itu sendiri yang mengalami transformasi, elemen-elemen dari luar juga masuk ke Aceh.

Kertas kerja ini mencoba merunut kembali politik identitas dengan mengetengahkan persoalan dan isu yang dihadapi dan ditanggapi secara serius oleh masyarakat Aceh; ${ }^{9}$ bagaimana masyarakat Aceh membuat wacana dan membentuk identitas dirinya atas isu yang berkaitan dengan dirinya sendiri, yaitu seputar penerapan syariah, kristenisasi, aliran sesat dan hegemoni Barat. Unsur-unsur itu penting dalam rangka pembentukan identitas, yang diungkap oleh masyarakat sendiri dari berbagai elemen dalam narasi.

\section{Penerapan Syariah di Aceh}

Setelah masa roformasi dan pasca-Tsunami, syariah bertambah melekat pada identitas keacehan. Semua informan bersemangat dalam menceritakan tema ini. Patut juga dicatat bahwa euforia ini juga

\footnotetext{
5 Ichwan, "Official Ulema and the Politics of Re-Islamization", 198.

6 Aspinall, "The Construction of Grievance," 959; Yusny Saby, "The Ulama in Aceh: A Brief Historical Survey," Studia Islamika, Vol. 8, No. 1 (2001), 1-54.

7 Michael Feener, Sharia and Social Engineering, the Implementation of Islamic Law in Contemporary Aceh (Oxford: Oxford University Press, 2013), 19.

8 Tentang euphoria kebebasan dan konservatisme pasca-reformasi bisa dilihat di $\mathrm{Al}$ Makin, "Revisiting Indonesian Public Reactions against Danish Cartoons Depicting Prophet Muhammad," Indonesian Journal of Islam and Muslim Societies, Vol. 5, No. 2 (2015), 195-229; Al Makin, "Benedict XVI and Islam: Indonesian Public Reactions to the Regensburg Address," Islam and Christian-Muslim Relations, Vol. 20, No. 4 (2009), 409-421.

9 Tentang identitas baru setelah Tsunami, lihat misalnya, Muhammad Nasir, "Syariat Islam dan Ngangkang Style: Mengenal Kearifan Lokal dan Identitas Perempuan Aceh," Miqot, Vol. 37, No. 1 (2013), 198-213; Ibnu Mujib, Irwan Abdullah, dan Heru Nugroho, "Gagasan Aceh Baru: Pembentukan Identitas Aceh dari dalam Reaktualisasi Ruang Publik bagi Aksi Pengelolaan Kearifan Lokal Pasca-Konflik dan Tsunami," Kawistara, Vol. 4, No. 1 (2014), 49-62.
} 
berlaku di daerah lain di Indonesia, tetapi Aceh tetap kental dengan identitasnya. Namun, dalam bagian ini tidak semua informan setuju dalam penerapan syariah konvensional Aceh, tetapi ada counter-wacana yang mempunyai pandangan lain.

Tengku Daud Rusli-pemimpin Dayah Salafi Abu Raufmeyakini bahwa pemerintah Indonesia sudah islami. Tidak perlu lagi umat Islam mendirikan negara Islam. Pada dasarnya, sila pertama dalam Pancasila sudah menggambarkan tauhid, yaitu keesaan Tuhan, maka syariat bukan berarti kita akan mendirikan negara Islam, hanya praktik islami yang berada di negara yang sudah Islam pada prinsipnya.

Tengku Daud Rusli tentu sangat mendukung program syariat di Aceh, di mana banyak program dari pemerintah lokal yang sudah mengarah ke pendidikan agama. Misalnya, pengajian bakda magrib, merupakan area pembelajaran tentang hakikat keislaman, ini juga sudah dianjurkan oleh pemerintah lokal Aceh. Menurut Rusli, pemerintah lokal sudah tepat memberi dorongan berlakunya syariah Islam di Aceh. Juga pemerintah pusat sudah mendukung program tersebut. ${ }^{10}$

Begitu juga Hasan, seorang impinan DDII (Dewan Dakwah Islam Indonesia) dan pernah menjadi WH (Wilayah Hisbat/polisi syariah) sangat mendukung penerapan syariah Islam di Aceh. Hasan menjelaskan bahwa:

Kalau pengurus DDII semua memajukan dan mendukung syariah Islam khusus di Aceh. Semua mempraktikkan (syariah). Itu menjadi proyek andalan di Aceh. Dari anggota-anggotanya ada yang WH. Tapi sudah habis (selesai masa tugas). Kalau di kabupaten kota ada yang WH. Sudah habis di WH (semua pemuda sudah menjadi anggota). ${ }^{11}$

Berbeda dengan Tengku Rusli yang cenderung puas dengan dukungan pemerintah lokal maupun pusat tentang pemberlakukan syariah di Aceh, Hasan mengeluh bahwa pemberlakuannya cenderung melambat. Harusnya, syariah sudah demikian maju dan semua lini kehidupan diatur oleh syariah.

Sejauh pantuan kami, pelaksanaan syariah di Aceh masih sangat lamban. Semestinya dari 2002 atau 2003 sudah ada sesuatu yang melambung. Tapi hal itu belum nampak. Kesalahan itu pada penguasa lokal Aceh dan juga keterbatasan kemampuan masyarakat. ${ }^{12}$

\footnotetext{
${ }^{10}$ Daud Rusli, Wawancara, Aceh 14 Juli 2013.

${ }^{11}$ Hasan, Wawancara, Aceh 13 Juli 2013.

12 Ibid.
} 
Tentu saja Hasan menuntut pemberlakuan syariah yang lebih kaffah: lebih total dari sudut semuanya. Ini belum terlaksana. Pemerintah pusat sendiri sepertinya mendukung orang Aceh dalam hal syariah. Kenyataannya, pemerintah pusat kurang mendukung dana pemberlakuan tersebut. Penerapan butuh dana yang tidak sedikit, paling tidak dalam satu hukuman ḩudûd yang dilaksanakan di masjid membutuhkan dana 20 juta. Ini membebani anggaran daerah. Jika pemerintah pusat tidak mendukungnya, maka penerapan syariah masih sulit.

Hasan juga menegaskan bahwa syariah Islam itu di atas hukum lain bahkan di atas hukum internasional seperti HAM (Hak Asasi Manusia). Keduanya nyatanya bertentangan. Menurut HAM, semua orang bisa bertukar agama. Menurut syariah tidak bisa. Ini pertentangan. Menurut penggiat HAM, dari sebagian LSM di Aceh, hukum cambuk itu bertentangan dengan HAM. Ini penghalang syariah di Aceh. Perlu diingat bahwa Islam itu ada dan mengajarkan hukum cambuk sebagai bagian dari ḅudûd (hukuman badan) sejak abad tujuh, sementara produk HAM itu dan modern. Jadi yang tidak bertemu dan tidak relevan. Bahkan kalau diteliti ulang, para pegiat HAM itu kadang tidak mengerti hakikat Islam. ${ }^{13}$

Pendukung syariatisasi lain adalah Sanusi, pimpinan MAA (Masyarakat Adat Aceh). Ia menegaskan bahwa penghalang syariah Islam itu tak lain para aktivis LSM, yang didanai pihak luar. Sanusi menegaskan:

Pada umumnya masyarakat (Aceh) menyambut dengan baik (syariah). Namun, perlu diperbaiki lagi terutama di bidang akidah. Di Aceh banyak organisasi non-Islam, NGO-NGO, yang menganggu masalah aqidah Aceh. ${ }^{14}$

Namun, counter-wacana datang dari masyarakat Aceh sendiri, yang mempunyai perspektif dan pandagan lain tentang syariah. Salah satunya adalah Tengku Burhanuddin, pemimpin Dayah di Babaherung, Kotabaru Aceh, yang mengatakan bahwa pemberlakuan syariah di Aceh itu keterlaluan. Seharusnya syariah itu hasil dari kesadaran sendiri, bukan diawasi dan dihukum di publik. Selama memimpin pesantren ia tidak pernah menjalankan penghukuman seperti itu. Seharusnya syariah itu dijalani dengan kesadaran dari

${ }^{13}$ Kritik tentang pandangan seperti ini juga dijumpai seperti Danial, "Syari'at Islam dan Pluralitas Sosial: Studi tentang Minoritas dan Non-Muslim dalam Qânûn Minoritas Islam Aceh)," Analisis, Vol. 12, No. 1 (2012), 71-92.

14 Sanusi, Wawancara, Aceh 16 Juli 2014. 
masyarakat, bukan paksaan. Ia berpandangan bahwa WH atau polisi syariah itu tidak perlu.

Sebagian daerah (syariah) bisa diaplikasikan. Pengawasannya terlalu ketat dan kejam. Di Lhoksumawe agak masif. Duduk ngakang di motor tidak boleh. Dalam beberapa hari di Aceh Timur, Tamiyang, pakaian ketat juga tidak diperkenankan. Sekarang tergantung pada individunya dulu. Masyarakat belum sadar aturan agama, apapun yang dilihat ya tidak jalan juga. Di pondok ini, ayah saya memberi ilmu pada mereka supaya patuh aturan negara syariah, tapi pemahaman tentang Islam itu yang harus ditanam. Bagi saya, kelompok WH itu tidak perlu. Kesadaran masyarakat yang penting. ${ }^{15}$

Demikian juga counter-wacana datang dari Syahrizal, aktivis LSM di PPD (Program Pendidikan Damai). Menurutnya, justru syariah Islam di Aceh sering menjadi pemicu kekerasan. Penghakiman massal sering terjadi. Jika masyarakat tidak puas terhadap Dinas Syariah Aceh, mereka melakukan tindakan sendiri untuk menghukum mereka yang kedapatan melakukan khalwat, yang umumnya para pemuda dan pemudi.

Para pelanggar terkadang dihakimi massa. Jika seseorang ketahuan sedang ber-khalwat, masyarakat langsung main hakim sendiri, dipukul dan semacamnya. Terkadang, masih ada masyarakat yang tidak puas dengan apa yang dilakukan oleh Dinas Syariat sendiri, termasuk pengawasnya, yaitu WH dalam menindaklanjuti pelanggar syariat. Secara umum tidak ada yang menolak syariat Islam, namun ketika ada pelanggaran di masyarakat, biasanya ditemukan tindak kekerasan. Ada main hakim sendiri. ${ }^{16}$

\section{Isu Kristenisasi}

Pembentukan identitas religius di Aceh juga berkaitan dengan kerisauan masyarakat pasca-bencana Tsunami tentang efek dari bantuan dari pihak asing yang datang ke Aceh. Kekhawatiran itu diungkapkan dengan adanya misi pihak asing dalam pemberian bantuan, yaitu upaya kristenisasi dalam masyarakat Aceh yang mayoritas Islam. Ini tercermin dalam wawancara dalam penelitian ini. Para informan banyak yang merasakan kristenisasi terselubung dalam berbagai bentuk. Dalam bentuk simbol misalnya, ada banyak salib

\footnotetext{
${ }^{15}$ Burhanuddin, Wawancara, Aceh 16 Juli 2013.

${ }^{16}$ Syahrizal, Wawancara, Aceh 17 Juli 2013.
} 
dalam bantuan mereka. Banyak salib terdapat di permen, buku-buku, dan juga barang-barang bantuan lainnya. ${ }^{17}$

Pembagian buku-buku di sekolah-sekolah juga merupakan modus yang banyak diungkapkan oleh para informan. Di beberapa sekolah dasar dan menengah para misionaris membagikan buku secara gratis untuk dibaca. Buku-buku itu berisi tentang ajaran Yesus dan gambargambar Bunda Maria. Bahkan menurut pengakuan sebagian informan, gambar-gambar itu sengaja dibawa untuk mempengaruhi para siswa.

Pembaptisan adalah isu penting. Di batas wilayah Aceh dan Sumatera Utara, yaitu Singkil, dicurigai orang-orang Aceh sebagai tempat pembaptisan warga dan pemuda Muslim ke Kristen. Di beberapa gereja di Banda Aceh, yakni di Penayeung, wilayah yang banyak dihuni oleh pedagang China dan mereka berasal dari Medan juga dicurigai sebagai tempat penyebaran Kristen. Isu juga sering diungkapkan oleh para informan bahwa banyak warga Aceh yang telah dikristenkan di Penayeung.

Atas isu Kristenisai ini, warga terpicu untuk melakukan kekerasan dengan berbagai bentuk. Pertama adalah penggerebekan secara massal tempat orang-orang yang dianggap Kristen berkumpul. Di Penayeung terjadi pengejaran dan penutupan gereja Kristen. Beberapa gereja di Banda Aceh juga ditutup. Yang menarik adalah para pemuka masyarakat mengumpulkan tokoh Kristen dan diajukan ke pemerintah lokal Aceh untuk mengadakan perjanian, berupa penutupan gereja Kristen, penghentian melakukan ibadah Kristen, dan tentu saja penghentian kegiatan misionaris.

Narasi kristenisasi, lewat misionaris bantuan asing, lalu terjadi kekerasan ini diakui Sanusi:

NGO itu didatangkan pihak asing. Sampai hari ini masih ada di Aceh, yang namanya missioneris. Baru-baru ini malah, saya membela misionaris sedang duduk di Penayeung. Hanya beberapa orang tinggal. Lalu mereka membuka pengajian. Lalu dilanjutkan sembahyang. Tempat itu akan dijadikan gereja. Terakhir terendus oleh Pemerintah Daerah, digerebeg, kedapatan dibawa ke WH dan polisi pamong praja. Kemudian komandannya di Medan meminta bantuan. Saya hubungi satpol PP dan WH, maka dibuat perjanjian. Setelah itu mereka dilepaskan. ${ }^{18}$

Ariwani, aktivis Wanita Indonesia (WI) juga mempunyai catatan khusus tentang Kristenisasi di Aceh:

17 Tentang diskriminasi terhadap minoritas karena pemberlakukan syariah Aceh, lihat misalnya, Danial, "Syari'at Islam dan Pluralitas Sosial".

${ }^{18}$ Sanusi, Wawancara, Aceh 16 Juli 2014. 
Menurut beberapa sumber, ada yang 600 orang Aceh yang dididik di Jawa dan Medan. Itu bencana besar di Aceh. Salah satu isu GAM adalah Sumatera Utara mengobok-obok (lewat) Kristenisasi. Pemerintah pusat tidak berbuat apa-apa. Banyak palang salib. Ada satu dan dua anak yang bisa lari. Jalur pendidikan juga disusup. Ada yayasan Sukma milik Surya Paloh, di mana satu tenaga ahlinya Kristen. Surya Paloh orang Aceh. Kita digempur semua lini. Ada anak TK, play group, homeschooling. Buku itu bukan hanya di sekolah. Di SMP manapun ada. Kita khawatir buku-buku seperti itu ada di rumah kita. Pasca-Tsunami buku-buku itu menyebar di sekolah-sekolah. Dulu buku itu, karena banyak pengarang. Tiap tahun ganti anak-anak. Ada buku lain. Ada buku lain. ${ }^{19}$

Tarmizi, pemimpin Front Pembela Islam (FPI) Aceh, juga membenarkan isu kristenisasi. Bahkan orang Kristen yang datang dan membawa misi ke Aceh rata-rata lewat simbol. Di samping mereka juga mendirikan gereja-gereja baru setelah Tsunami. ${ }^{20}$

Ahmad Yanis, seorang aktivis Pelajar Islam Indonesia (PII) juga sangat tertarik ketika diajak berbicara tentang isu kristenisasi. Katanya:

Pasca-Tsunami sempat dibentuk tim oleh pemerintah (untuk meneliti

Kristenisasi). Kristenisasi yang berkedok kemanusiaan. Buktinya, ada semacam ajaran-ajaran Injil masuk lewat kegiatan psycho healing. Ada buku-buku cerita yang untuk anak-anak yang muatan ceritanya adalah nilai-nilai Kristen. Kemudian juga bentuk hipnotis. Sempat ada yang murtad dan dibaptis. ${ }^{21}$

Menurut Yanis, Kristenisasi itu sangat aktif terutama di daerah perbatasan dengan Medan, seperti Singkil. Sementara pemerintah pusat tidak banyak berbuat apa-apa. Hanya sekadar membentuk tim, tetapi tidak sampai intervensi melarang upaya Kristenisasi.

Dengan isu Kristenisasi ini, kekerasan juga muncul. Pertama adalah penggerebekan tempat ibadah. Ini terjadi di Penayeung, gereja yang dijadikan ibadah bagi para pendatang dari Medan, Ambon, dan Jawa. Penggerebekan ini terjadi hingga penghancuran tempat tersebut. Para jemaah trauma atas penggerebekan ini, karena massa yang datang ratusan. Ketika pendetanya, Niko dari Medan, di-interview, ia mengaku tidak ada upaya Kristenisasi. Mereka sebagai pendatang hanya melaksanakan ibadah sendiri. Jangankan menambah anggota gereja, anggota tetap berkurang terus karena takut. Banyak jemaah di gereja itu yang memilih meninggalkan Aceh dan pulang ke daerah masing-

${ }^{19}$ Ariwani, Wawancara, Aceh 14 Juli 2014

20 Tarmizi, Wawancara, Aceh 13 Juli 2013.

21 Ahmad Yanis, Wawancara, Aceh 14 Juli 2013. 
masing ketika kepentingannya sudah usai. Jadi, Kristenisasi yang ditakutkan itu benar-benar isu yang meresahkan, karena tidak ada bukti, dan hal itu justru mengarah pada kekerasan.

Berikut ini keterangan Tirimizi yang sangat aktif dalam membendung gerakan kristenisasi:

Di Aceh ada 7 gereja di Singkil. Di Banda ada 15 geraja ilegal. Semua ada 20, ilegal 15. Itu pemerintah tidak berani. FPI yang tidak takut. 27 di Singkil. Di Banda, ilegal 15, jumlah total 20. Yang legal 5. Itulah nilai Aceh, tidak ada yang legal. Maka orang Aceh sangat damai. Tapi kalau aturannya dirongrong kita harus berkelahi. ${ }^{22}$

Setelah gereja itu didata, lalu didatangi dengan massa. Setelah itu mereka digiring untuk dibawa ke Pemda dan diadakan perjanjian untuk menutup gerejanya. Begitulah rumor Kristenisasi yang berakibat pada tindakan diskriminasi, intimidasi, dan kekerasan.

\section{Isu Aliran Sesat}

Sama dengan isu kristenisasi, isu adanya aliran sesat juga membentuk identitas keacehan dalam semangat religius yang menjaga kemurnian Islam. Patut juga dicatat, isu aliran sesat dan nabi palsu merupakan bagian dari menguatkan konservatisme, radikalisasi, dan ortodoksi Islam di Indonesia. ${ }^{23}$ Untuk Aceh yang hangat menjadi isu adalah aliran Millata Abraham, yaitu gerakan aliran baru yang beroperasi di kampus-kampus dan sekolah. Sekte ini berusaha menarik banyak pengikut dengan tujuan mengajak kembali ke akar agama Semitik, yaitu Ibrahim. Dengan begitu sekte ini bisa mengakomodasi Kristen, Yahudi, dan Islam. Aliran ini sempat sukses karena di samping cara perekrutan yang baik, juga ditopang oleh keanggotaan yang rapi. Namun, pada akhirnya para pemimpin masyarakat Aceh resah atas aliran ini. Mereka menuntut pembubaran karena dianggap sesat dan mengancam Islam di Aceh.

Penulis bertemu dengan Ahmad Yanis, misalnya, aktivis PII, yang mengaitkan kemunculan aliran ini dengan konspirasi internasional. Yahudi, dan Amerika, yang dianggap terlibat dalam pembentukan aliran ini untuk mengacaukan umat Islam. Sementara pemerintah pusat Jakarta tidak berbuat sesuatu untuk mengatasinya.

Millata Abraham itu diciptakan oleh siapa? Tapi saya curiga ada kaitan dengan jaringan internasional itu. Yahudi terlibat dan selalu terlibat.

22 Tarmizi, Wawancara, Aceh 13 Juli 2013

${ }^{23}$ Diskusi tentang ini untuk wilayah Indonesia lihat misalnya Al Makin, Challenging Islamic Orthodoxy: Accounts of Lia Eden and Other Prophets in Indonesia (Dordrecht, Holland; Cinnaminson [N.J.], U.S.A.: Springer, 2016). 
Amerika secara negara tidak terlibat, tetapi ada organisasi semacam rahasisa yang mempengaruhi itu. Termasuk kebijakan politik setiap negara itu. ${ }^{24}$

Pimpinan Majelis Ulama Aceh (MPU), Abdullah Atibi, juga terlibat dalam penggerebekan Millata Abaraham. ${ }^{25}$ Berikut ini kutipan wawancaranya:

125 orang (yang menjadi anggota Millata Abraham) itu termasuk mahasiswa di Unsyiah, hampir 90 persen. Ada juga dari IAIN yang masuk Millata Abraham. Ada Islam sedikit, Kristen sedikit, campur baur, sinkretisme itu lebih kuat. Itu 2010 (sekte millata Abraham berdiri), tahun 2011 kita tangkap mereka. Setelah selesai, ada semacam pejanjian. Yang menangkap itu saya sendiri. Di Pungai Jurung pada jam 12 malam, bulan Oktober $2010 .^{26}$

Abdullah Atibi terlibat dalam penggerebekan salah satu pimpinan Millata Abraham, yaitu Jamaluddin, yang ditangkap malam hari. Kemudian melaporkan ke Polisi yang kemudian datang, dan menangkapnya. Jamaluddin itu, menurut informasi yang dikumpulkan Atibi, adalah dosen di salah satu Perguruan Tinggi swasta di Aceh. Kata Atibi, "Saya bawa, dari sana ke pesantren Hasbi Bayuni, kampung Bayu. Jam 1 malam, saya telepon ketua MPU, dan wakil ketua yaitu Ramli Yusuf, dan Karim Seh. Kami bertiga dan masyarakat bergabung dengan kapolsek. Kita buatkan perjanjian, di mana mereka tidak mengajarkan yang salah-salah dan akan tobat."

Dengan pemaksaan akhirnya Jamaluddin dan rekan-rekannya bersedia berbalik ke ajaran Islam. Katanya, anak Jamaluddin yang baru berumur 10 tahun, bernama Zainuddin akan menjadi nabi bagi para pengikutnya. Menurut ajaran ini, Nabi Muhammad sudah tidak lagi relevan untuk diikuti karena sudah tidak mampu menangani persoalan umat masa kini. Maka perlu ada nabi baru. Muhammad juga diutus hanya untuk orang Arab saja. Dengan pengaruhnya, MPU menghadap ke wakil gubernur Muhammad Nazar yang kebetulan juga menyetujui tindakan itu. Dibuatlah perjanjian hitam di atas putih agar sekte ini membubarkan diri, berhenti mengadakan aktivitas dan tidak lagi menyebarkan ajarannya.

\footnotetext{
24 Ahmad Yanis, Wawancara, Aceh 14 Juli 2013.

${ }^{25}$ Pembahasan tentang peran ulama Aceh yang berkurang bisa dilihat di Aslam Nur, "Ulama dalam Dinamika Sosial dan Budaya Masyarakat Aceh di Awal Abad Kedua Puluh Satu," Humaniora, Vol. 23, No. 3 (2011), 315-325.

${ }^{26}$ Abdullah Atibi, Wawancara, Aceh 14 Juli 2013.
} 
Ada dua kasus lagi yang menonjol yang sempat menjadi bahan perbincangan dan menjadi berita di berbagai surat kabar, yaitu pembakaran dan pembunuhan Dayah Tengku Ayub dan pembubaran Dayah Miftahussaadah. Menurut cerita, kedua Dayah tersebut dituduh sesat, lalu massa datang membakarnya, termasuk di dalamnya pemimpinnya Tengku Ayub dan beberapa anggota.

Sama juga dengan syariatisasi, ada counter-wacana dalam hal ini, tidak semua setuju dengan ortodoksi dan konservatisme. Tengku Muhammad Jafar, aktivis di LSM FIRLA, mengatakan bahwa kasus 'kesesatan' itu secara teologi sulit dibuktikan.

Tengku Ayub itu dituduh sesat. Saya diberi cerita oleh kawan saya. Tidak hadir. Feri di Kontras Aceh, sekarang di Jakarta. Dia langsung di lokasi. Membeli kitab yg diajarkan Ayub. Sampai tengah malam. Dia tidak menemukan itu (tuduhan itu terbukti). Tidak ada yang sesat dan lain-lain itu (seperti yang dituduhkan). ${ }^{27}$

Demikian juga dengan kasus Miftahussaadah yang dituduh sesat karena tidak menjalankan Salat Jumat. Maka masyarakat sekitar menuduh kelompok ini sesat:

Kasus Miftahussaadah dipolitisir oleh pemain lokal yang terjadi di bulan Februari 2013. Dikatakan bahwa tengku Mualimin (pemimpin Dayah Miftahussaadah) tidak pernah salat jumat. Dia pernah tiga kali salat jumat di (desa) tetangga. Karena dia diserang oleh khatib (dikatakan sesat). Sebanyak itu dia diserang dan sesat. Setelah itu ia memilih tidak pergi lagi. ${ }^{28}$

Persoalannya, adalah kecemburan sosial ekonomi. Konon, dua Dayah itu, Tengku Yakub dan Miftahussaadah, mempunyai sumber ekonomi yang lebih dibandingkan dengan Dayah-Dayah lain di desa tetangga. Dayah dan rumah Tengku Yaqub itu terbuat dari bata dan lebih bagus dari rumah-rumah dan Dayah-Dayah dari desa sekitar. Juga ditambah dengan sedikit eksklusivitas, masyarakat sepetinya mudah dihasut, apalagi jika dikaitkan dengan ortodoksi. Di atas juga disebut bahwa MPU berperan dalam hal penyudutan dan pemfatwakan aliran sesat itu.

\section{Barat sebagai Musuh}

Wacana Barat sebagai musuh tercermin dalam wawancara beberapa informan yang merefleksikan jati diri keacehan. Sama juga dengan isu lain, ini pun juga terdapat counter-wacana. Namun kita mulai dari yang mewacanakan Barat sebagai pihak yang

${ }^{27}$ Muhammad Jafar, Wawancara, Aceh 16 Juli 2013.

${ }^{28}$ Ibid. 
bertanggungjawab terhadap kericuhan di Islam dan Aceh, yang merupakan identitas mereka.

Tarmizi, pemimpin FPI Aceh, mengatakan: "Pasti ada kerjasama antara Indonesia dan Amerika utuk menerkam Islam, terutama pada persoalan ekonomi. Mereka ingin melemahkan ekonomi kita. Orang yang punya kekayaan bisa mempertahankan keislaman dan keacehan. Sedangkan yang lemah ekonomi, mereka akan sulit bertahan." Namun Tarmizi dalam melihat Amerika saat ini juga lain. Ia mengatakan: "Kemarin presiden Amerika Obama mengatakan Islam bukan agama teroris. Itu menarik, indah. Orang Kristen bisa berkata seperti itu. Mungkin Obama mempelajari Islam yang sebenarnya““. ${ }^{29}$

Yang mendukung wacana seperti ini adalah Ahmad Yanis, aktivis PII. Ia menegaskan Amerika tetap musuh utama Islam. Ia berujar:

"Musuh-musuh Islam ya yang seperti di berita-berita itu sebagaimana yang diungkapkan dari analisa-analisa intelejen, internet, atau yang ditulis oleh pakar-pakar. Negara dua adidaya, seperti Amerika dan Eropa kurang kelihatan kontribusinya, underbow-nya lah. Otaknya di Israel yang memang bercita-cita menghancurkan Islam. ${ }^{30}$ Kalau Australia tidak punya banyak kepentingan. Sedangkan Amerika mengatur dan menyusup ke segala penjuru, seperti soal impor sapi yang selalu ada masalah. Kalau coba-coba berani, seperti Menkes Siti Fadilah, terkait virus SARS, dan kepentinganya ekonomi Amerika menjual vaksin itu. Siti Fadilah pun diberhentikan. ${ }^{31}$

Amerika di sini dikaitkan langsung dengan Yahudi dan Kristen. Agama kedua sering dicurigai sebagai agama yagn menyusup langsung di Aceh. Sedangkan yang pertama identik dengan kekuatan Amerika. Keduanya dianggap berperan dalam politik nasional Indonesia dan lokal Aceh. Yang menarik adalah keterkaitan antara semua isu utama kita: Yahudi, Kristen, Amerika, Kristenisasi dan aliran sesat. Yahudi dianggap menyusup dalam konspirasi politik untuk menghancurkan negara-negara Islam. Salah satu usahanya adalah menyokong aliran sesat seperti Millata Abraham. Kristen juga bergerak sendiri dan didukung pula secara finansial oleh Amerika. Jadi isu tersebut dalam bayangan dan asumsi banyak informan saling terkait. Inti utama dalam perbincangan adalah Islam versus kafir, yang kedua secara terus menerus dianggap merongrong Islam.

\section{Identitas Religius}

29 Tarmizi, Wawancara, Aceh 13 Juli 2013.

${ }^{30}$ Ahmad Yanis, Wawancara, Aceh 14 Juli 2013.

${ }^{31}$ Ibid. 
Narasi religius yang terselubung dalam isu syariatisasi, kristenisasi, aliran sesat, dan hegemoni Amerika itu tersebar dalam benak informan dengan berbagai macam cara dan dalam konteks yang berbeda-beda. Jika ingin memahaminya lebih mendalam, kita perlu mengaitkan dengan konteks utama kita, yaitu sejarah konflik Aceh yang berkepanjangan dan bagaimana perubahan peta itu pascaTsunami. Aceh merupakan daerah yang merasa berbeda, agama dan keacehan menyatu dan membentuk jati diri.

Persoalan pemberlakuan syariah adalah persoalan identitas bagi masyarakat Aceh. Itu yang membedakan dengan provinsi lain. Jika ditempat lain ada semacam pergerakan ke Arah ortodoksi seperti yang terjadi di Jawa dan mungkin provinsi lain di Sumatera, di mana para pemain politik lokal memanfaatkannya untuk pepentingan politik lokal pula, Aceh mempunyai catatan sejarah yang panjang bagaimana Syariah menjadi bagian dari identitas mereka. Dalam narasi identitas tentu harus dipahami bagaimana Aceh merupakan bagian dari Indonesia adalah hasil dari tawar menawar antara identitas lokal mereka dan bagaimana mereka bersedia berkompromi dan menerima narasi nasionalisasi Indonesia. Ini tidak mudah. Identitas keacehan dengan syariatnya selalu menancap di pikiran dan pola pikir masyarakat Aceh.

Ketika Aceh di bawah kepemimpinan Daud Bereuh bersedia bergabung dengan Indonesia, syariah menjadi bahan utama dalam negosiasi. Ini terefleksi dalam salah satu wawancara kami dengan $\mathrm{Al}$ Kaf, seorang aktivis di Aceh Institut:

Ada yang membedakan antara Aceh dan bagian lain Indonesia pada sejarah politik dan konflik (di Aceh). Saya lihat kontestasi Islam dan negara di Aceh, di mana secara kultural orang Aceh menjadikan syariah sebagai pilihan. Dalam dialaog-dialog dalam Daud Bereuh dan Sukarno tentang syariah (dan negara), nilai tawarnya soal syariah. ${ }^{32}$

Syariah sepertinya-meminjam kata beberapa informan sendirisudah menjadi darah daging Aceh. Lebih singkatnya dalam bahasa ilmiah, syariah merupakan politik identitas masyarakat Aceh. Namun, semenjak Orde Baru, isu agama terpinggirkan dari ruang pulbik. Ini terjadi tidak hanya di Aceh, tetapi di semua konstalasi politik di Indonesia pada umumnya. Isu syariah menjadi reda. Namun, politik menjadi harganya. Sepertinya, karena syariah merupakan bagian dari jati diri Aceh, maka jika jati diri atau identitas itu dipinggirkan, harus

32 Al Kaf, Tarmizi, Wawancara, Aceh 16 Juli 2013. 
ada harga yang dibayar, yaitu konflik yang berkepanjangan. Konflik dengan pemerintah yang berkepanjangan itu, tentu saja tidak hanya persoalan syariah, juga tidak pula pesoalan agama secara umum, tapi persoalan identitas. Aceh merasa berbeda dengan bagian lain Indonesia, dan yang membedakan itu, menurut narasi yang mereka ungkapkan pada kami adalah syariah.

Pada masa reformasi, terjadi euforia di seluruh wilayah Indonesia. Agama datang lagi ke ruang publik. ${ }^{33}$ Begitu juga kondisi di Aceh. Tema syariah menjadi hangat lagi, dan sepertinya menggugah ingatan dan identitas lama yang selama ini dipaksakan untuk dikesampingkan oleh Orde Baru. Begitu kata Al Kaf:

Tahun 2000-an pada titik krusial, kita tidak siap lagi, pada kultural (Aceh yang hilang), sudah tidak siap. Karena peran Orde Baru, peminggiran agama, membuat (kita) tidak siap. Ketika isu-isu agama dihadirkan lagi ke ruang public, plus tuntutan Aceh pada soal HAM dan kelompok GAM, mendesak etno-nasionalisme. 1962 isu-isu agama terpinggirkan. ${ }^{34}$ Konstelasi politik lokal ini menarik sekali, saat di mana isu disintegritas bangsa Indonesia menjadi topik utama pembicaran dan wacana nasional, berbagai upaya para pemimpin politik di Jakarta mempertahankan negara ini. Timor Timur baru saja terpisah, dan akhirnya menjadi negara merdeka Timur Leste. Mereka tidak siap lagi jika Aceh juga mengikuti jejaknya, yakni lewat referendum. Gus Dur dalam hal ini, cukup jitu menawarkan dan menghembuskan lagi isu syariah sebagai kompensasi. Tapi yang menarik adalah Megawati yang paling punya peranan dalam mewacanakan kembali syariah sebagai jati diri dan identitas politik di Aceh.

Gus Dur pada saat itu aktif kampanye NKRI. Bisa jadi pemerintah pusat mendorong syariah untuk menunjukkan pada Barat bahwa Aceh fundamentalis, juga tarik-menarik dengan GAM. Paling enak ya menghadirkan syriah. Yang menaikkan syariah itu PDIP, bukan Gus Dur. Itu menimbulkan banyak pertanyaan. ${ }^{35}$

\footnotetext{
33 Makin, Challenging Islamic Orthodoxy; Makin, "Benedict XVI and Islam"; Makin, "Revisiting Indonesian Public Reactions"; Al Makin, "Pluralism versus Islamic Orthodoxy, the Indonesian Public Debate over the Case of Lia Aminuddin, the Founder of Salamullah Religious Cult," dalam Thomas J. Conners (ed.), Social Justice and Rule of Law: Addressing the Growth of a Pluralist Indonesian Democracy (Tembalang, Semarang, Central Java, Indonesia; [New Haven: Faculty of Social and Political Sciences, Diponegoro University; Yale Indonesia Forum, 2010), 187-206.

34 Al Kaf, Tarmizi, Wawancara, Aceh 16 Juli 2013.

${ }^{35}$ Ibid.
} 
Isu pemberlakuan syariah tentu bisa dikatakan isu internal masyrakat Aceh sendiri. Namun, dalam bercampurnya isu ini dengan integrasi dan disintegrasi masyarakat Indonesia pada umumnya, maka isu syariah menjadi wacana secara nasional. Terbukti Aceh merupakan model bagi daerah-daerah lain untuk mengikutinya. Syariah sebagai peraturan daerah yang disahkan secara politik lokal tidak hanya terjadi di Aceh, tetapi di daerah daerah lain juga marak.

Penyebaran narasi tentang syariah bisa disimpulkan melalui dua chanel: Pertama adalah lokal Aceh sendiri, sebagai bagian dari identitas, kedua dari konstalasi politik nasional, sebagai hasil kompromi antara pemerintah pusat sebagai kompensasi dari tuntutan politik identitas di Aceh.

\section{Momentum Pasca-Tsunami}

Saat ini persoalan menjadi lain ketika pasca-Tsunami. Tsunami mempunyai efek yang luar biasa bagi masyarakat Aceh, tidak hanya bencana itu sendiri mempunyai efek secara psikologis, tetapi secara sosial dan politik, bencana alam ini mempunyai konsekuensi tersendiri yang patut diperhitungkan dalam menyusun narasi tentang Aceh. Pertama setelah Tsunami perjanjian antara pemimpin lokal Aceh dan pemerintah pusat di Helsinki dapat terwujud, yang memupuskan keinginan untuk sementara pemimpin lokal menggunakan identitas Aceh untuk mendorong referendum. Kedua, Tsunami juga membuka datangnya berbagai pihak ke Aceh. Ini tentu juga mempengaruhi pola interaksi sosial, pandangan hidup, dan juga pembentukan pola narasi tentang jati diri mereka. Pihak asing tidak hanya membawa bantuan untuk para korban (sebagaimana isu ini selalu dimunculkan hampir semua informan dalam penelitian ini), tapi juga berinteraksi dengan orang Aceh dengan pola tertentu antara orang asli dan pendatang (atau sebutan persisnya sebagai tamu). Ini tentu mempunyai dampak bagaimana orang Aceh bersikap terhadap pihak asing. Bisa jadi, banyak kalangan yang dalam pergaulan yang memanggil ulang identitas mereka tentang betapa unik dan berbedanya orang Aceh jika dibandingkan dengan para tamu tersebut. Waktu berhembusnya isu disintegritas di bawah bayangan antara konflik GAM dan RI, rakyat Aceh merasa berbeda dengan Indonesia, kini ketika pasca-Tsunami ia merasa berbeda dengan penduduk dunia yang lainnya. Perbedaan dan jati diri jadi meluas skala dan perbandingannya. Intinya, secara identitas, Tsunami mempunyai dampak yang mendalam dalam penyusunan peta narasi tentang identitas keacehan. 
Ada dua hal yang menjadi bahan utama identitas keacehan: orang lain, liyan. Bayangan mereka dan konsepsi mereka tentang orang Jawa (yang dipandang sebagai pilar utama pemerintah pusat Jakarta), dan yang kedua adalah bayangan mereka tentang Barat (mewakili persepsi tentang non-Muslim). Tentang narasi orang Jawa masih terlihat kental, walaupun terjadi perubahan, ketika interaksi langsung pasca-Tsunami. Begitu juga bayangan mereka tentang Barat. Maka, bisa dikaitkan antara isu Syariah, Kristenisasi, aliran sesat dan hegemoni Jawa dalam konteks nasional juga Barat dengan konteks global.

Pengerucutan isu pasca-Tsunami juga perlu dicatat. Paling tidak isu Kristenisasi, aliran sesat, dan hegemoni Barat itu bertambah tajam pasca-Tsunami, setelah isu konflik antara pemerintah pusat dan lokal Aceh tidak lagi mengemuka dan mendominasi narasi mereka. Pusat versus Aceh tidak lagi menjadi bahan utama perbincangan, tetapi keislaman dan keacehan bersatu dalam membentuk identitas baru.

Hasan, seorang aktivis DDII, mengungkapkan sebagai berikut:

Pemerintah pusat tidak ada upaya apa-apa. Polisi sebagai pihak kemaanan saja melaksanakan tugas. Yang menghalangi Islam di sini adalah pihak asing. Tidak bisa dikatakan pemerintah pusat, seperti tidak peduli dan membiarkan saja. ${ }^{36}$

Dari kalimat tersebut bisa ditarik benang merah. Pemerintah pusat sudah tidak lagi berperan sebagai lawan, tetapi Hasan memandang skeptis peran positif dari pemerintah pusat. Dari peran sebagai penghalang, menjadi pembiaran dari pemerintah pusat. Tentu proses Kristenisasi dan aliran sesat, pemerintah pusat tidak berkontribusi, atau sengaja mengirim orang dengan mazhab yang tidak sesuai dengan mazhab yang dipeluk oleh orang Aceh, tetapi pemerintah pusat hanya membiarkan itu terjadi. Yang menjadi sasaran sebagai musuh adalah pihak luar, yang disangka mendanai, mendukung aliran sesat sebagaimana diyakini oleh Ahmad Yanis, Tarmizi, dan lain-lain dalam narasi di atas.

Teuku Zulkhori, salah satu aktivis RTA (Rabithah Taliban Aceh) mengungkapkan seperti ini: "Isu kristenisasi di Aceh dalam konteks Aceh, persoalan besar. Caranya misalnya, mengiming-imingi uang dan lain-lain setelah Tsunami dan sampai sekarang". ${ }^{37}$ Pasca-Tsunami bisa menjadi benang merah tersendiri untuk menandai sejarah

\footnotetext{
${ }^{36}$ Hasan, Wawancara, Aceh 13 Juli 2013.

37 Zulkhoiri, Wawancara, Aceh 16 Juli 2013.
} 
pembentukan narasi tentang identitas Aceh, karena semua dikembalikan ke sana.

Sanusi, pemimpin Masyarakat Adat Aceh (MAA), juga calon legislatif dari PAN mengatakan seperti ini:

Pasca-gempa Tsunami banyak sekali dalam obat-obatan terdapat palang salib. Pun buku-buku bantuan yang diberikan. Karena distribusi bantuan itu melalui saya, maka saya mengetahuinya. Tapi karena waktu itu kita perlu bantuan tersebut untuk masyarakat; yang kita pisahkan ya kita pisahkan, yang tidak bisa kita salurkan ke masyarakat. ${ }^{38}$

\section{Penetrasi Unsur luar}

Walaupun menurut narasi politik identitas Aceh, keacehan itu sendiri adalah unik dan lahir dari konsep lokalitas, tetapi saling mempengaruhi antara wacana yang ada di Aceh dan di luar Aceh tetap intens. Terutama setelah bencana Tsunami, keterbukaan itu tidak hanya berpengaruh secara tidak langsung terhadap pembentukan identitas, tetapi pengaruh langsung berupa paham radikalisme, dan konservatisme bisa dilihat. Dua diantara informan mengatakan, bahwa sebelumm Tsunami, tidak ada organisasi semacam HTI (Hisbut Tahrir Indonesia) dan FPI di Aceh. Dua organisasi itu ada karena pengaruh Jawa.

Seorang aktivis FIRLA, Tengku Muhammad Jafar, mengatakan bahwa paham kekerasan di Aceh itu seperti dimasuki dari paham yang sudah berkembang di Jawa. Terutama pasca-Tsunami, banyak organisasi-organisasi dari Jawa melakukan penetrasi ke Aceh. FPI dan HTI dahulu tidak ada di Aceh, namun pasca-Tsunami merupakan momentum, sehingga mereka masuk wilayah Aceh. Berikut bisa ditampilkan apa yang diungkapkan oleh Jafar:

Di Aceh kini pasca-Tsunami, persoalan mulai masuk, seperti hadirnya FPI dan HTI sebagaimana yang tertuang dalam buku Serambi Makkah berubah. Ketika Habib Rizieq ke Aceh, ia berkunjung ke Dayah. Mereka menolak FPI. Dia mengatakan Aceh pasca-konflik, jangan seperti ini. Dengan kehadiran FPI di Aceh justru akan menambah konflik. Ulama Dayah seperti Walidno masih punya gambaran seperti itu. Akhirnya, FPI bisa masuk lewat Tengku Muslim Tahiri dari Dayah Darul Mujahidin di Aceh Utara. Dia yang menggantikan FPI di bawah Yusuf Qardawi, adik angkatan saya di kampus IAIN. Qardawi punya peran besar membuat FPI bisa diterima dan establibsed di Aceh, dan akhirnya

${ }^{38}$ Ibid. 
diterima. Mereka punya basis di Dayah. Segala penegakan syariah Islam, FPI masuk ke permukaan. ${ }^{39}$

Sukurdi, aktivis di LSM Aceh Institut, berpendapat lain, bahwa mungkin saja Jamaah Islamiyah (JI) itu ada di Aceh. Karena organisasi ini menggunakan metode menyusup, sehingga keberadaannya dimungkinkan di Aceh. Namun, sampai saat ini, sebagai organisasi yang paling banyak bertanggungjawab atas peristiwa kekerasan dan pengeboman belum mengemuka di Aceh. Tetapi ia berpendapat bahwa kalau ada kekerasan atas nama Islam, dengan mengambil tema Barat sebagai musuh yang harus dihancurkan, Aceh tidak ada tempat. Di Aceh tidak berdiri kedutaan Amerika, Eropa atau Inggris. Dengan begitu, tidak ada alasan untuk mengebom Aceh.

Sukurdi mengingat bahwa dulu ada kelompok yang ekstrem dan radikal di Aceh yang mencoba mengaitkan kegiatan global di dunia ini dengan ideologi mereka. Mereka mencoba mengadakan demonstrasi di depan gedung Uni Eropa House di Jalan Sudirman dekat Ketapang di Aceh. Namun gedung itu tidak ada kaitannya dengan ketentaraan, justru gedung itu tempat promosi perdamaian. Maka tentu demo mereka salah alamat. Gedung itu kini sudah tutup. Maka Sukurdi tetap beranggapan bahwa kekerasaan, ekstremisme, dan terorisme mungkin bisa berkembang di Aceh. Ini berbeda pandangan dengan informan lainnya. Tetapi momen yang belum mereka dapatkan. ${ }^{40}$

Bisa disimpulkan dari pola penyebaran narasi bahwa jati diri atau identitas keacehan itu terbentuk berkat sejarah Aceh sendiri yang unik, terutama relasinya dengan pusat dan perlu ditempatkan bagaimana konflik RI dan lokal Aceh itu berlanjut dan berakhir. Syariah sebagai jati diri adalah unsur penting dalam sejarah Aceh. Isu Kristenisasi, aliran sesat, dan hegemoni Barat terbentuk, dan sepertinya terdorong secara tajam, saat pasca-Tsunami di mana interaksi antara para tamu dengan Aceh terjadi. Itulah yang membentuk narasi baru dan wacana yang berkembang di Aceh hingga kini.

\section{Counter-wacana Isu Keagamaan di Aceh}

Counter-wacana tentang Kristenisasi, aliran sesat, syariah dan hegemoni Barat terjadi di Aceh. Ada beberapa organisasi, yang biasanya diisi oleh anak muda Aceh, yang berwawasan terbuka. Mereka tidak menentang syariatisasi secara terbuka di publik. Tetapi

\footnotetext{
${ }^{39}$ Muhammad Jafar, Wawancara, Aceh 16 Juli 2013.

${ }^{40}$ Sukurdi, Wawancara, Aceh 16 Juli 2013.
} 
mereka menawarkan kaca pandang baru dan mempertanyakan apa itu syariah. Syariah diartikan tidak hanya sesempit budûd. Syariah juga bukan berarti penghakiman dan peraturan daerah. Ia lebih luas dari itu.

Dalam menyikapi Kristenisasi, dari beberapa organisasi, seperti Aceh Institut, ICOAS, FIRLA menawarkan narasi lain. Terjadi isu itu karena kesalahpahaman dari masyarakat. Kristenisasi tidak pernah betul-betul mengancam Aceh, tidak pula mengancam umat Islam secara umum.

Tengku Burhanuddin, yang mempunyai narasi tandingan berupa tidak perlunya $\mathrm{WH}$, dan penghukuman di publik bagi pelanggar syariah di Aceh, belajar di Dayah dan MIN. Burhanuddin saat ini tinggal di Babaherung, Kotabarau, Aceh Besar. Ia belajar bahasa Arab sejak kecil. Melanjutkan sekolah Tsanawiyah di Banda Aceh, malamnya belajar lagi di Dayah. Ia juga alumni IAIN Ar-Raniry di fakultas Tarbiyah. Sedangkan Tengku Ibrahim merupakan guru di Tsanawiyah. Ia juga merawat Dayah Saifuddin di Lamprit.

Tokoh yang cukup vokal menyuarakan narasi lain, bernama Sukurdi, yang aktif di LSM Aceh Institut. Ia juga berdagang di sekitar masjid Baiturrahman. Dulu ia berkuliah di IAIN fakultas Dakwah, lulus tahun 2005. Ia juga meneruskan S2 di Unsyiah, mengambil bidang pendidikan. Ia juga aktif di berbagai diskusi di kelompok ICAIOS (Unsyiah-IAIN Ar-Raniry).

Al Kaf, yang merupakan lulusan S2 di UIN Yogyakarta, juga aktif di Yayasan Pendidikan Ali Hasyimi dari tahun 2013. Namun, sejak tahun 2005 aktif di Aceh Institut. Al Kaf juga Muazin di masjid Baiturrahman. Bapak dan kakeknya ulama ternama di Aceh. Al Kaf menyelesaikan SD sampai dengan S1 di Banda Aceh. S1 ia mengambil komunikasi di fakultas Dakwah. Sekarang ia juga mengajar di dakwah dan syariah tentang tema Komunikasi dan politik. Ia menawarkan kritikan yang sangat tajam soal syariatisasi, kristianisasi, dan hegemoni Barat.

Informan yang juga mencoba mempunyai pandangan terbuka tentang narasi identitas politik di Aceh adalah Tengku Muhammad Jafar. Ia adalah lulusan S1 Fakultas Syariah Progam Studi Jinayah Siyasah di IAIN Arraniry. Ia melanjutkan S2 IAIN Arraniry dalam bidang pemikiran Islam. Pendidikan dasar SD, SMP, dan MAN ia selesaikan di Sabang. Ia pindah ke Banda tahun 1999 sampai selesai kuliah tahun 2005. Ia tinggal di Banda Aceh sudah enam tahun. Sejak 
mahasiswa ia aktif di SMUS (Solidaritas Mahasiswa ke Rakyat), organisasi yang agak kekiri-kirian. Sekarang ia aktif di Forum Islam Rahmatan Lil Alamin (FIRLA), juga di Jaringan Masyarakat Sipil Peduli Syariah (JMSPS). FIRLA sendiri berdiri April 2011. Jafar langsung aktif di situ. Organisasi ini didirikan pasca peristiwa pembakaran Dayah Tengku Ayub.

Ternyata, masyarakat Aceh tidaklah homogen, tetapi dinamis. Ada wacana yang mengusung identitas etno-religius yang mengedepankan kesalehan, ortodoksi, dan konservatisme. Namun dalam masyarakat itu sendiri terdapat counter-wacana yang menawarkan perbedaan.

\section{Penutup}

Narasi identitas masyarakat Aceh yang bersandar pada agama dan etnisitas (etno-religius) bisa dilihat dari wacana yang berkembang di masyarakat tersebut. Identitas itu bisa ditelusuri dalam ekspresi mereka ketika menyampaikan kekhawatiran akan merebaknya isu-isu yang mengurangi atau mengancam identitas itu, yaitu syariatisasi, kristenisasi, aliran sesat dan hegemoni Barat. Narasi yang dikemukakan menggambarkan kentalnya rasa keacehan yang merasa berbeda dengan daerah lain karena unsur etnis dan agama yang dipegang; bercampur dengan ortodoksi dan islamisasi. Pengaruh gerakan keterbukaan dan demokratisasi pasca-reformasi tentu terasa karena unsur-unsur luar yang masuk ke Aceh juga bisa dirasakan dalam ekspresi mereka. Namun keunikan identitas Aceh tetap kental yang bisa terbaca bagaimana mereka mengungkapkan kekhawatiran akan kehilangan jati diri. Syariatisasi merupakan ciri khas dan gerakan yang banyak didukung oleh politisi lokal dan masyarakat. Kristenisasi mengancam rasa keislaman, terutama pasca-Tsunami. Aliran sesat juga bisa mengancam keislaman, dan kemurniannya. Hegemoni Barat juga ketakutan dari kenyataan bahwa bantuan selama bencana Tsunami ternyata banyak mengandung unsur Barat. Namun, wacana ini tidak tunggal; narasi tidak satu. Ada yang memberikan suara lain (counterwacana) dari kelompok muda yang berafiliasi dengan beberapa NGO di sana. Kelompok ini mencoba mendudukan persoalan dengan isuisu tadi dan memberi jawaban lain atas persoalan, tidak hanya berdasarkan identitas Aceh, tetapi berdasarkan kenyataan dan perspektif lain. Ini nada lebih positif dan optimis dalam memandang Aceh di dunia. 


\section{Daftar Rujukan}

\section{A. Buku dan Jurnal}

Aspinall, Edward. "The Construction of Grievance: Natural Resources and Identity in a Separatist Conflict," The Journal of Conflict Resolution, Vol. 51, No. 6, 2007.

Bustamam-Ahmad, Kamaruzzaman. "The Application of Islamic Law in Indonesia: The Case Study of Aceh," Journal of Indonesian Islam, Vol. 1, No. 1, 2007.

Danial. "Syari'at Islam dan Pluralitas Sosial: Studi tentang Minoritas dan Non-Muslim dalam Qânûn Minoritas Islam Aceh)," Analisis, Vol. 12, No. 1, 2012.

Feener, Michael. Sharia and Social Engineering: the Implementation of Islamic Law in Contemporary Aceh. Oxford: Oxford University Press, 2013.

Ichwan, Moch. Nur. "Official Ulema and the Politics of ReIslamization: The Majelis Permusyawaratan Ulama, Shariatization and Contested Authority in Post-New Order Aceh," Journal of Islamic Studies, Vol. 22, No. 2, 2011.

Makin, Al. "Benedict XVI and Islam: Indonesian Public Reactions to the Regensburg Address," Islam and Christian-Muslim Relations, Vol. 20, No. 4, 2009.

"Pluralism versus Islamic Orthodoxy, the Indonesian Public Debate over the Case of Lia Aminuddin, the Founder of Salamullah Religious Cult," dalam Thomas J. Conners (ed.), Social Justice and Rule of Law: Addressing the Growth of a Pluralist Indonesian Democracy. Tembalang, Semarang, Central Java, Indonesia; [New Haven: Faculty of Social and Political Sciences, Diponegoro University; Yale Indonesia Forum, 2010.

----. "Revisiting Indonesian Public Reactions against Danish Cartoons Depicting Prophet Muhammad," Indonesian Journal of Islam and Muslim Societies, Vol. 5, No. 2, 2015.

----. Challenging Islamic Orthodoxy: Accounts of Lia Eden and Other Prophets in Indonesia. Dordrecht, Holland; Cinnaminson [N.J.], U.S.A.: Springer, 2016.

Keragaman dan Perbedaan: Budaya dan Agama dalam Lintas Sejarah Manusia. Yogyakarta: Suka Press, 2016.

Mujib, Ibnu. Abdullah, Irwan. dan Nugroho, Heru. "Gagasan Aceh Baru: Pembentukan Identitas Aceh dari dalam Reaktualisasi Ruang Publik bagi Aksi Pengelolaan Kearifan Lokal PascaKonflik dan Tsunami," Kawistara, Vol. 4, No. 1, 2014. 
Nasir, Muhammad. "Syariat Islam dan Ngangkang Style: Mengenal Kearifan Lokal dan Identitas Perempuan Aceh,” Miqot, Vol. 37, No. 1, 2013.

Nur, Aslam. "Ulama dalam Dinamika Sosial dan Budaya Masyarakat Aceh di Awal Abad Kedua Puluh Satu," Humaniora, Vol. 23, No. 3, 2011.

Saby, Yusny. "The Ulama in Aceh: A Brief Historical Survey," Studia Islamika, Vol. 8, No. 1, 2001.

Salim, Arskal. "Shari'a from Below' in Aceh (1930s-1960s): Islamic Identity and the Right to Self-Determination with Comparative Reference to the Moro Islamic Liberation Front (MILF)," Indonesia and the Malay World, Vol. 32, No. 92, 2004.

-----. "Dynamic Legal Pluralism in Indonesia: Contested Legal Orders in Contemporary Aceh," Journal of Legal Pluralism, Vol. 10, No. 61, 2010.

Siregar, Hasnil Basri. "Lessons Learned from the Implementation of Islamic Shari'ah Criminal Law in Aceh," Journal of Law and Religion, Vol. 24, No. 1, 2009.

Srimulyani, Eka. "Islam, Adat and the State: Matrifocality in Aceh Revisited," Al-Jami'ab: Journal of Islamic Studies, Vol. 48, No. 2, 2010.

\section{B. Wawancara}

Al Kaf, Tarmizi. Wawancara. Aceh 16 Juli 2013.

Ariwani. Wawancara. Aceh 14 Juli 2014

Atibi, Abdullah. Wawancara. Aceh 14 Juli 2013.

Burhanuddin. Wawancara. Aceh 16 Juli 2013.

Hasan. Wawancara. Aceh 13 Juli 2013.

Jafar, Muhammad. Wawancara. Aceh 16 Juli 2013.

Rusli, Daud. Wawancara. Aceh 14 Juli 2013.

Sanusi. Wawancara. Aceh 16 Juli 2014.

Sukurdi, Wawancara. Aceh 16 Juli 2013.

Syahrizal, W awancara. Aceh 17 Juli 2013.

Tarmizi, Wawancara. Aceh 13 Juli 2013.

Yanis, Ahmad. Wawancara. Aceh 14 Juli 2013.

Zulkhoiri, Wawancara. Aceh 16 Juli 2013. 